\title{
Effect of energy sources on ovarian follicular dynamics and oestrous activity of Holstein cows
}

\author{
B.A. Useni ${ }^{1 \#, ~ C . J . C . ~ M u l l e r ~}{ }^{1,2} \&$ C.W. Cruywagen ${ }^{1}$ \\ ${ }^{1}$ Department of Animal Sciences, University of Stellenbosch, Private Bag X1, Matieland 7602, South Africa; ${ }^{2}$ Western \\ Cape Department of Agriculture, Research and Technology Development Services, Directorate: Animal Sciences, \\ Private bag X1, Elsenburg 7607, South Africa
}

(Received 6 November 2017; Accepted 13 June 2018; First published online 30 July 2018)

\author{
Copyright resides with the authors in terms of the Creative Commons Attribution 4.0 South African Licence. \\ See: http://creativecommons.org/licenses/by/4.0/za \\ Condition of use: The user may copy, distribute, transmit and adapt the work, but must recognise the authors and the South African \\ Journal of Animal Science.
}

\begin{abstract}
The objective of the study was to evaluate the effects of three nutritional treatments, which differed in energy level and source, on preovulatory follicles, number of follicles and oestrous activity in dairy cows. Twenty two Holstein multiparous cows from the Elsenburg herd were used in this study. After parturition, cows were kept on kikuyu-ryegrass pastures on an ad libitum basis, and allocated to various levels and types of concentrate supplements, which differed in starch and fat contents. The control group received $7 \mathrm{~kg} /$ day of a control concentrate, and the treatment groups each received $12.6 \mathrm{~kg} /$ day of concentrate. The concentrates contained high starch-low fat (HSLF) and high starch-low fat/low starch-high fat (HSLF-LSHF) levels. The supplement in treatment HSLF was a glucogenic concentrate using maize as the energy source. The supplements in treatment HSLF-LSHF were a combination of a glucogenic concentrate, which was offered for the first 60 days in milk (DIM), similar to treatment HSLF, followed from 61 DIM by a lipogenic concentrate using wheat bran and calcium (Ca) salts of long-chain fatty acids as the energy sources. At $80 \pm 10$ DIM, cows were synchronized with an Ovsynch protocol without being inseminated before the ultrasonography observation. While they were detained in a shaded neck clamp, cows were assessed individually with an ultrasound scanner every three days for ovarian measurements and follicular activity until the subsequent oestrus. Results showed that ovarian and follicular measurements and the numbers of follicles in various follicle size classes were similar between nutritional treatments. However, the total ovarian follicular counts were significantly higher in cows that received the HSLF and HSLF-LSHF treatments, compared with their counterparts in the control group (i.e. $7.23 \pm 0.22,7.21 \pm 0.14$ and $6.53 \pm 0.19$, respectively), through possible improvement in nutritional status. Further research is required to investigate various energy levels and sources that enhance the viability and the quality of the oocyte ovulating from the dominant follicle and improve the intensity and length of the oestrous expression in dairy cows.
\end{abstract}

Keywords: Energy nutrients, follicular numbers, heat expression, preovulatory follicle, ruminant

\# Corresponding author: alainub83@gmail.com

\section{Introduction}

Optimizing fertility in dairy herds requires cows to calve annually to maximize the economic returns from milk production (Roche et al., 2000). However, several studies have reported a worldwide decline in fertility of dairy cows (Lucy, 2007; Butler, 2003; Walsh et al., 2011). The peripartum negative energy balance (NEB) in dairy cows could last for 10 to 12 weeks postpartum (Butler, 2003) and suppresses the somatotropic axis and gonadotropins on the ovaries (Beam \& Butler, 1999), resulting in extended anoestrous periods (Butler, 2000; Mellouk et al., 2017). Roche et al. (2000) stressed that anovulatory oestrus in dairy cows is not owing to an absence of follicular development, but to the failure of a dominant follicle to ovulate, because of an NEB. Anoestrus is caused by low levels of metabolites (i.e. glucose) and hormones (i.e. insulin, insulin-like growth factor-I (IGF-I), luteinizing hormone (LH) and oestradiol) in the bloodstream (Beam \& Butler, 1999; Diskin et al., 2007). The decline in these metabolic and endocrinal signals reduces the diameter and growth rate of the dominant follicle (Beam \& Butler, 1997), prevents or delays it from ovulating (Butler, 2003; Webb et al. 2004), and eventually decreases the weight of the corpus luteum after ovulation 
(Beam \& Butler, 1999). Also, ovaries of cows that were exposed to adverse conditions of NEB were reported to be small in size and low in follicular counts (Ireland et al., 2008), they produced low levels of oestrogens and progesterone $\left(\mathrm{P}_{4}\right)$ after ovulation (Leroy et al., 2008a), and they were associated with poor endometrial development (Jimenez-Krassel et al., 2009). Wathes et al. (2007) reported that inferior oocytes were produced in dairy cows at the start of the breeding season when ovarian follicles underwent their earlier stages of maturation during the NEB nadir. Additionally, studies in which dairy cows were monitored using milk $\mathrm{P}_{4}$ profiles found that NEB was associated with greater incidence of irregular oestrous cycles (Taylor et al., 2003; Wathes et al., 2003). Consistent with these arguments, NEB has been shown to have adverse long-term carry-over effects on fertility through ovarian dysfunction and reduced oocyte competence (Britt, 1994; Lucy, 2007; Leroy et al., 2008a; 2008b; Garnsworthy et al., 2008a). Thus the ultrasound imaging technique offers a way to investigate bovine follicular dynamics to understand the ovarian function on fertility in dairy cows (Sakaguchi et al., 2004; Mossa et al., 2012). Real-time ultrasonographic imaging allows noninvasive visual assessment of changes in ovarian structures over time (Fricke, 2002). Therefore, the objective of this study was to evaluate the effects of inclusion level (low versus high) and type of energy supplements (starch versus fat) on preovulatory follicles, numbers of follicles and oestrous activity in Holstein cows grazing on kikuyu-ryegrass pastures following oestrous synchronization.

\section{Materials and Methods}

Ethical clearance for this study was obtained from Western Cape Department of Agriculture (WCDA, Project AP/BR/D/CM31).

The trial was conducted at Elsenburg Research Farm of the WCDA, located approximately $50 \mathrm{~km}$ east of Cape Town, at an altitude of $177 \mathrm{~m}$, longitude of $18^{\circ} 50^{\prime}$ and latitude of $33^{\circ} 51^{\prime}$ in the winter rainfall region of South Africa. The area receives an average annual rainfall of $650 \mathrm{~mm}$, and has a typical Mediterranean climate with short cool wet winters and long warm dry summers.

In this study, the ovarian follicular dynamics and oestrous activity of 22 multiparous Holstein cows (i.e. $3.89 \pm 0.40$ years old in their second and third parities) were assessed over an oestrous period ( \pm 21 days). Following parturition, cows were allocated to three isonitrogenous nutritional treatments, namely control $(n=$ 10), high starch-low fat (HSLF) $(n=6)$ and high starch-low fat/low starch-high fat (HSLF-LSHF) $(n=6)$, according to calving date, LW at calving and milk yield during the previous lactation. Cows were offered unrestricted access to cultivated kikuyu-ryegrass pastures, and were supplemented with pelleted concentrates, which differed in energy level and type. Pastures were irrigated, as required, using a permanent irrigation system. Cows followed a rotation programme to ensure an ad libitum dry matter (DM) intake under normal conditions. The control group received $7 \mathrm{~kg} /$ day of a control concentrate, while the treatment groups were fed concentrates at $12.6 \mathrm{~kg} / \mathrm{day}$. Half of the concentrate allowance was fed after each milking. Cows were milked twice a day at 05:30 and 15:00. Representative samples of pastures and concentrates were collected weekly, then bulked monthly, and analysed for chemical composition. Neutral detergent fibre (NDF) was determined according to Van Soest et al. (1991), using sodium sulphite anhydrous and amylase to decrease nitrogen and starch contamination in the NDF determination. AOAC (1990) official methods were used to determine the concentrations of DM, fat, crude protein (CP) and nitrogen $(\mathrm{N} \times 6.25)$ in the diet. Diets were formulated on a DM basis with the CPM-Dairy software programme (2006), using an intake level of $25 \mathrm{~kg} \mathrm{DM} /$ day per animal and consisted of the various levels and types of concentrate offered among treatments, with the rest of the intake being supplied by pastures. Starch and metabolizable energy (ME) of diets were estimated using the CPM-Dairy software programme (2006).

The control concentrate consisted of maize as the energy source. It contained a low level of energy content, and was fed from calving until the end of the trial. The control diet provided 10.3 MJ ME/kg DM and 457, 104 and $40 \mathrm{~g} / \mathrm{kg} \mathrm{NDF}$, starch and fat on a DM basis, respectively. The supplement in the HSLF treatment was a glucogenic concentrate containing maize as the energy source, and was fed from calving until the end of the trial. The HSLF diet contained a high energy content (11.3 MJ ME/kg DM) and offered 341,242 and $35 \mathrm{~g} / \mathrm{kg}$ of NDF, starch and fat on a DM basis, respectively. This HSLF diet was formulated to increase the circulating glucose and insulin levels to improve the postpartum EB status and encourage ovarian activity in cows. The supplements in the HSLF-LSHF treatment were combinations of a glucogenic concentrate, which was offered for the first 60 DIM per treatment HSLF, followed from 61 DIM until the end of the trial by a lipogenic (LSHF) concentrate using wheat bran and Ca salts of long-chain fatty acids (Megalac rumen bypass fat, Volac International Ltd., UK) as the energy sources. In the HSLF-LSHF combination treatment, the high starch-based diet was fed to achieve the same objective as the HSLF treatment during the first 60 DIM. The LSHF diet contained a high level of energy (11.3 MJ ME/kg DM) and was formulated to provide 388, 137 and $58 \mathrm{~g} / \mathrm{kg}$ of NDF, starch and fat on a DM basis, respectively. The LSHF diet was fed from 61 DIM to decrease plasma insulin and improve plasma cholesterol to increase ovulatory follicular competence. 
At $80 \pm 10$ DIM, 22 cows were synchronized using an Ovsynch protocol without subsequent insemination. Cows were handled individually with care, while restrained in a sheltered neck clamp. The synchronization procedure began in early August 2014, and followed this pattern: i) at 11:00 on day 0, cows received an intravaginal progesterone $\left(P_{4}\right)$ controlled internal drug release device (CIDR) (Pfizer

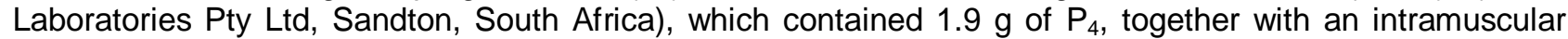
injection of $2 \mathrm{~mL}$ of Cidirol (Pfizer Laboratories Pty Ltd, Sandton, South Africa), which contained $1 \mathrm{mg} / \mathrm{mL}$ of oestradiol benzoate in $100 \mathrm{mg} / \mathrm{mL}$ of benzyl alcohol as preservative; ii) on day 7, animals received an intramuscular injection of $1 \mathrm{~mL}$ prostaglandin- $\mathrm{F}_{2 \alpha}\left(\mathrm{PGF}_{2 \alpha}\right)$ Estrumate, containing $0.1 \% \mathrm{~m} / \mathrm{v}$ of chlorocresol as preservative and $263 \mu \mathrm{g}$ of cloprostenol sodium, equivalent to $250 \mu \mathrm{g}$ of cloprostenol (Schering-Plough Animal Health, Isando, South Africa) at 16:00; iii) on day 8, CIDR devices were removed at 07:00 and heat detectors (Kamar ${ }^{\circledR}$ Heatmount Detectors, Kamar Products Inc., Zionsville, USA) were attached to the tailhead area; iv) on day 9 , a dose of $1 \mathrm{~mL}$ of $\mathrm{PGF}_{2 \alpha}$ was administrated by an intramuscular injection; and v) on day 10, cows were not inseminated, but the positive heat detectors were removed. Ovaries were then subjected every three days at 15:00 to an ultrasonographic evaluation for the next $21 \pm 3$ days until the subsequent oestrus. To avoid ultrasonographic procedures on Sundays, an interval of four days was sometimes used. The diagnostic imaging was performed with an ultrasound scanner (SonoScape A6, SonoScape Medical Corp., Shenzhen, China), with a linear transrectal probe and standardized settings. Settings were 5-6 MHz for the frequency, $80 \%$ for power and $62 \mathrm{~mm}$ for depth. This procedure was conducted by one trained veterinarian for all cows to minimize variation. The Kamar detectors were attached to cows on day 9 from the start of the ultrasound observation, and cows were artificially inseminated when oestrous detection was positive. The Kamar detector was positive when cows showed typical oestrous behaviours (i.e. mucous vaginal discharge, mounting and sniffing). The trial was completed after a pregnancy diagnosis by rectal palpation by the veterinarian at 35-40 days after artificial insemination (Al).

Ovarian follicles, which were observed as black circular fluid-filled structures, were identified on all digitized images (Fricke, 2002). An electronic calliper was used to measure the diameters of the ovaries and follicles. The relationship between the measured dimensions on the digitized images and the calculated dimensions on the ultrasound was determined with established linear regression $\left(y=0.392 x, R^{2}=0.84\right)$. All visible follicles were counted on both ovaries following each ultrasound observation and the total number of follicles per animal was noted, as were the areas (eclipses) of the ovaries over time. The area of the eclipse was measured as area $=3.142 \times$ short radius $x$ long radius, with short and long radiuses being half of their diameters. Follicles were categorized in relation to the long diameter in size classes according to Garnsworthy et al. (2008c). Small-sized follicles were $<5 \mathrm{~mm}$, medium-sized 5 to $10 \mathrm{~mm}$ and large-sized $>$ $10 \mathrm{~mm}$ in diameter.

Data were analysed using the PROC MIXED of SAS enterprise guide (SAS, 2012). The statistical model included the treatment $(T)$ effect, time $(t)$ effect of observations and interaction effect between treatment and time $(T t)$ as fixed effects, while animal effect within treatments was specified as a random effect. The measured variables obtained in an ultrasound observation during the trial were regarded as repeated observations of a particular block. The statistical model was defined as follow:

Model $=\mu+T_{i}+t_{j}+(t T)_{i j}+\delta_{(i j) k}+\varepsilon_{i j k}$, where

$\mu=$ overall mean

$T_{i}=$ the fixed effect of the $i^{\text {th }}$ treatment (i.e. control, HSLF and HSLF-LSHF)

$t_{j}=$ the fixed effect of the $j^{\text {th }}$ time of ultrasound observation (i.e.1 to 7)

$(t T)_{i j}=$ the interaction between levels $i^{\text {th }}$ treatment and $j^{\text {th }}$ time of ultrasound observation

$\delta_{(i i) k}=$ the variable effect of the $k^{\text {th }}$ block effect in the $i^{\text {th }}$ treatment (repeated statement)

$\varepsilon_{i j k}=$ the random experimental error

All effects were used to analyse the ovarian dimensions. The follicular counts were analysed without the repeated statement $\left(\delta_{(i j) k}\right)$ in the statistical model. The area of the preovulatory follicle at the first ultrasound observation was analysed without the repeated statement $\left(\delta_{(i j) k}\right)$ and interactions between treatment and time of ultrasound observation using the treatment as the only fixed effect in the statistical model. Statistical assumptions were described as fixed effects and their interactions were equal to zero with $\delta_{(i j) k} \sim \mathrm{N}\left(0, \sigma_{e}{ }^{2}\right)$, varying independently of $\varepsilon_{i j k}$. Differences in means and standard error (SE) of means between treatments were obtained using the pairwise comparison of the Bonferroni t-test and significance was declared at $P<0.05$. Interactions were reported as NS (not significant) if $P>0.05$.

\section{Results and Discussion}

The effects of concentrate supplementation that differed in energy level and type in a pasture-based system on ovarian and follicular dimensions, follicular counts and proportions of dairy cows that were ovulating or pregnant are presented in Table 1. Changes in total ovarian follicles of dairy cows over time of observation until the subsequent oestrus are showed in Figure 1. 
Table 1 Effects of nutritional treatments that differed after calving in energy levels and sources on ovarian and follicular dimensions, follicular counts (means \pm SE) and proportions of Holstein cows ovulating and pregnant after an Ovsynch protocol, recorded during a $21 \pm 3$-day period

\begin{tabular}{|c|c|c|c|c|c|c|}
\hline \multirow[b]{2}{*}{ Parameters } & \multicolumn{3}{|c|}{ Concentrate feeding } & \multicolumn{3}{|c|}{$P$-values } \\
\hline & Control & HSLF $^{1}$ & HSLF-LSHF $^{1}$ & $T^{2}$ & $t^{2}$ & $T t^{2}$ \\
\hline \multirow{2}{*}{\multicolumn{7}{|c|}{ Ovarian and follicular dimensions }} \\
\hline & & & & & & \\
\hline Short diameter of the ovary $(\mathrm{mm})$ & $16.2 \pm 0.42$ & $16.3 \pm 0.43$ & $16.1 \pm 0.32$ & 0.22 & 0.76 & NS \\
\hline Long diameter of the ovary (mm) & $33.1 \pm 0.62$ & $33.4 \pm 0.79$ & $33.7 \pm 0.81$ & 0.32 & 0.87 & NS \\
\hline Ovarian area $\left(\mathrm{mm}^{2}\right)$ & $426 \pm 15$ & $437 \pm 19$ & $445 \pm 20$ & 0.29 & 0.73 & NS \\
\hline Area of preovulatory follicles at first observation $\left(\mathrm{mm}^{2}\right)$ & $115 \pm 15$ & $167 \pm 21$ & $131 \pm 19$ & 0.16 & - & - \\
\hline \multicolumn{7}{|l|}{ Follicular counts } \\
\hline Number of small follicles & $3.16 \pm 0.36$ & $3.46 \pm 0.42$ & $3.58 \pm 0.30$ & 0.19 & 0.09 & NS \\
\hline Number of medium follicles & $2.04 \pm 0.17$ & $2.48 \pm 0.22$ & $2.16 \pm 0.24$ & 0.42 & 0.08 & NS \\
\hline Number of large follicles & $1.30 \pm 0.08$ & $1.29 \pm 0.11$ & $1.44 \pm 0.11$ & 0.58 & 0.07 & NS \\
\hline Number of total follicles & $6.53^{\mathrm{a}} \pm 0.19$ & $7.23^{b} \pm 0.22$ & $7.21^{b} \pm 0.14$ & 0.03 & 0.09 & NS \\
\hline \multicolumn{7}{|l|}{ Proportion of cows ovulating and pregnant ${ }^{3}$} \\
\hline Proportion of cows ovulating after Ovsynch & 1.00 & 0.83 & 1.00 & - & - & - \\
\hline Proportion of cows showing oestrous expression & 0.50 & 0.66 & 0.83 & - & - & - \\
\hline Pregnancy rate after $\mathrm{Al}$ & 0.40 & 0.50 & 0.50 & - & - & - \\
\hline
\end{tabular}

${ }^{1}$ HSLF: high starch-low fat, HSLF-LSHF: high starch-low fat/low starch-high fat

${ }^{2} T$ : treatment, $t$ : time of ultrasound observation, $T t$ : Interaction between treatment and time of ultrasound observation

${ }^{3}$ Not statistically analysed due to the small dataset $(n=22)$

$\mathrm{a}, \mathrm{b}, \mathrm{c}$ Row means with different superscripts differ significantly at $P<0.05$

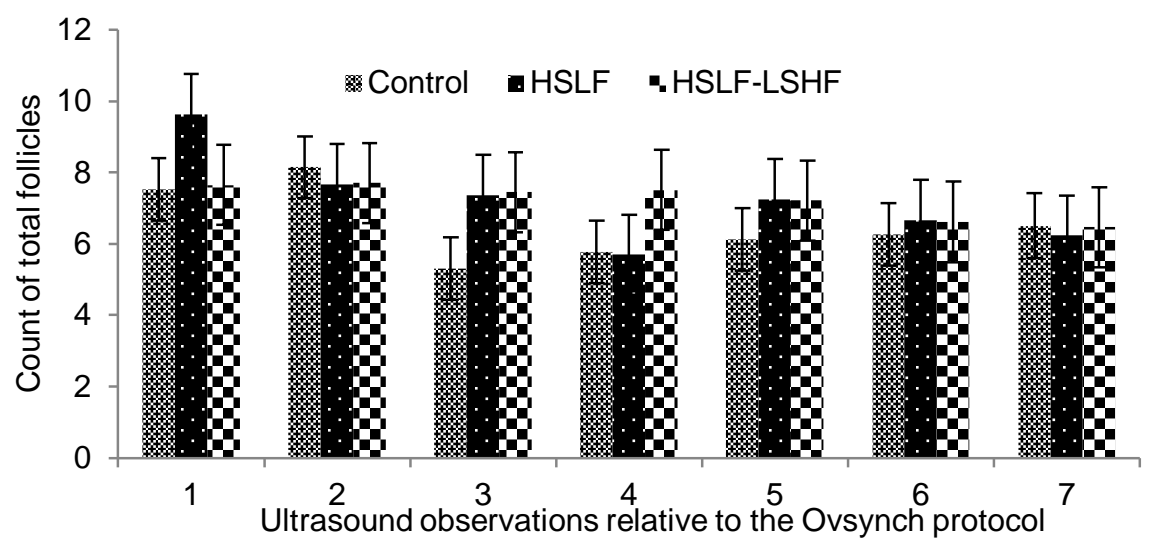

Figure 1 Effects of nutritional treatments differing after calving in energy levels and sources on the total number of ovarian follicles (mean \pm SE) following an Ovsynch protocol, recorded during a $21 \pm 3$ day period [HSLF: high starch-low fat, HSLF-LSHF: high starch-low fat/low starch-high fat]

The mean ( \pm SE) area of the bovine ovaries between nutritional treatments was $436 \pm 18 \mathrm{~mm}^{2}$, with a long diameter of $33.5 \pm 0.74 \mathrm{~mm}$ and a short diameter of $16.2 \pm 0.39 \mathrm{~mm}$. The ovarian dimensions of grazing Holstein cows were similar between nutritional groups that differed in inclusion level and type of concentrate supplements. No interaction effects between the treatment and the time of observation were detected on the ovarian dimensions of cows. Furthermore, the area of the preovulatory follicle, regarded as the largest follicle at the first ultrasound observation of cows, was similar among nutritional treatments. Energy levels and types among treatments did not affect the number of follicles in the various follicle size classes of dairy cows. However, cows that received $12.6 \mathrm{~kg}$ concentrate per cow per day in the HSLF and HSLF-LSHF treatments increased $(P<0.05)$ the number of total follicles, both amounting to $15 \%$ more follicles, in comparison with cows that received only $7 \mathrm{~kg}$ concentrate/cow/day in the control. 
Although the molecular mechanisms that are involved in the acquisition of competence are not well known, the size of the preovulatory follicle is an important parameter, which influences oocyte competence (Blondin et al., 2012). Lonergan et al. (1994) and Blondin \& Sirard (1995) studied in vitro the effect of follicular size on the quality and viability of oocytes in dairy cows, and found that oocytes that emerged from smaller follicles $(<3 \mathrm{~mm})$ had reduced or no developmental competence. These researchers reported that these oocytes appear to have been recovered too early and therefore probably lacked some follicular factors that would have signalled the oocytes to acquire their full competence. These factors, consisting of maternal messenger RNA and protein molecules, are synthesized and stored in a time, space and dose-dependent manner in the nucleus and ooplasma during oocyte growth and maturation (Blondin et al., 2012). Barnes et al. (1993) reported that an oocyte that ovulates from a larger dominant follicle has higher developmental competence in quality and viability. This competence is the ability of the oocyte to complete maturation, undergo successful fertilization, reach the blastocyst stage and yield a healthy embryo (Watson, 2007). Vasconcelos et al. (2001) studied the effect of follicle aspiration and gonadotropin-releasing hormone treatment on the size of follicles and corpus luteum of lactating dairy cows using an in vivo system. These researchers reported that increased follicle sizes in non-aspirated cows had advantageous effects on the corpus luteum function and its secretion of oestrogen and $\mathrm{P}_{4}$, compared with the aspirated group. In other investigations, no differences were recorded in the preovulatory follicle diameter (area $=3.412 \times R^{2}$, with $R$ being the radius) when isocaloric diets, which differed in increasing levels of starch and fat, were fed to lactating Holstein dairy cows (Garnsworthy et al., 2008b; 2008c). In the current study, the areas of the preovulatory follicle were $45 \%$ and $14 \%$ larger in lactating dairy cows fed the HSLF and HSLF-LSHF treatments compared with those fed the control diet, respectively. However, the recorded difference was not significant $(P=0.16)$, possibly owing to the small number of cows used in the study $(n=22)$.

In the current study, the number of follicles in the follicle size classes was similar between dairy cows fed various energy levels and types of concentrate. However, total follicular counts were improved $(P<0.05)$ in dairy cows fed HSLF and HSLF-LSHF concentrates compared with those that received the control concentrate, being $7.23 \pm 0.22,7.21 \pm 0.14$ and $6.53 \pm 0.19$, respectively. Mellouk et al. (2017) found no differences in numbers of small $(3-5 \mathrm{~mm})$, medium $(>5$ and $\leq 7 \mathrm{~mm})$ and large $(>7 \mathrm{~mm})$ follicles of dairy cows when fed diets containing high and low energy levels. Adamiak et al. (2005) studied the follicular growth in 20-month-old beef $x$ dairy heifers fed 5 or $10 \mathrm{MJ}$ ME/kg of metabolic LW per day. These researchers found no effect on the total number of visible follicles, but an increased number of medium-sized $(4-8 \mathrm{~mm})$ and large $(>8 \mathrm{~mm})$ follicles and improved growth rate and maximum diameter of the dominant follicles when feeding the high metabolizable energy (ME) diet compared with the low ME diet. On the other hand, Gong et al. (2002a) studied the ovarian follicular responses to follicle stimulating-hormone (FSH) treatment in Hereford $x$ Friesland heifers fed on a DM basis $2 \mathrm{~kg}$ of hay $+2.5 \mathrm{~kg}$ of concentrates at maintenance level and $2 \mathrm{~kg}$ of hay $+6.5 \mathrm{~kg}$ of concentrates at twice maintenance level. They found that feeding heifers at twice the maintenance level resulted in a significant increase in the number of small (2-4 $\mathrm{mm}$ ) and large (> $9 \mathrm{~mm}$ ) follicles. Lucy et al. (1991a) found that the energy balance (EB) status in early lactation influenced early changes in follicular populations of lactating dairy cows and reported decreasing numbers of small $(<5 \mathrm{~mm})$ ovarian follicles and increasing numbers of large $(>8 \mathrm{~mm})$ follicles, with increasing days postpartum. In addition, lactating dairy cows supplemented with lipids in early lactation in an attempt to improve the EB status were found to have follicles with larger diameters (Lucy et al., 1991b). Beam \& Butler (1997) studied the influence of EB status and level of dietary fat on the dominant follicle development and function in lactating Holstein cows. They found that follicles that emerged after the NEB nadir, rather than before the nadir, showed improved follicular growth and diameter, enhanced oestradiol production, and were more likely to participate in ovulation. Although insulin and IGF-I levels were not measured in this study, these hormones are signals that mediate critical changes in EB status. These hormonal improvements in postpartum dairy cows support the number, differentiation and maturation of follicles (Roche et al., 2011), thereby increasing oestradiol production (Gong et al., 2002b) and the chance of dominant follicles ovulating in response to the LH surge (Beam \& Butler, 1997; 1999; Lucy, 2003). Supporting this argument, NEB, which is a physiological state of undernutrition, has been related to the inability of the pituitary gland to sustain high-frequency LH pulses to the ovaries, resulting in the prevention of ovulation (Schillo, 1992; Jolly et al., 1995). Several reports indicated that energy sources could be manipulated via ingredients in the diet to prevent or treat peripartum NEB and improve the fertility of dairy cows (Staples et al., 1998; Gong et al., 2002b; Van Knegsel et al., 2007; Garnsworthy et al., 2008b; 2008c; Santos et al., 2008). Increasing the supply of glucogenic contents in the diet of dairy cows exerts a stimulating effect at ovarian level (Letelier et al., 2008), encouraging folliculogenesis (Scaramuzzi et al., 2011) and early resumption of oestrous cycles (Gong et al., 2002b). However, excessive insulin and IGF-I levels from high starch-based diets may overstimulate the ovarian developmental competence of oocytes and thus yield inferior oocytes in dairy cows (Armstrong et al., 2001; Laskowski et al., 2016). The decrease in 
the quality and viability of oocytes occurs as the synthesis and accumulation of maternal messenger RNA and protein molecules are uncoupled in an insulinogenic condition during oocyte growth and maturation (Leroy et al., 2008b). In contrast, feeding high fat diets after a voluntary waiting period, such as in the HSLFLSHF treatment, increased the number and size of follicles and the oestradiol secretion of the preovulatory follicle (Lucy et al., 1991b; Beam \& Butler, 1997; Moallem et al., 2007), probably via the induction of high cholesterol levels in the follicular fluid and the corpus luteum (Van Knegsel et al., 2007; Santos et al., 2008). In the present pasture-based study, HSLF and HSLF-LSHF treatments were designed to provide isocaloric concentrates that differed in starch and fat contents at an inclusion level of $12.6 \mathrm{~kg} / \mathrm{day}$, compared with 7 $\mathrm{kg} /$ day of concentrate in the control group. The total number of ovarian follicles (Figure 1) showed a positive relationship with the inclusion levels (high versus low) of concentrates, demonstrating increased ovarian follicular growth in dairy cows. Such enhanced follicular dynamism suggested improvements of specific receptors, metabolites and hormones that signal follicular growth in dairy cows. This positive effect in the current study could be attributed to the levels of concentrate supplements provided in the HSLF and HSLFLSHF treatments, improving the nutritional status (i.e. total digested nutrients and ME) compared with the control. This nutritional improvement had possibly optimized the hypothalamic-pituitary-ovarian axis and the energy carry-over effect into follicular and ovarian function, compared with the control.

The proportions of cows showing oestrous expression in the subsequent oestrus were $0.50,0.66$ and 0.83 for the control, HSLF and HSLF-LSHF, respectively (Table 1). The proportion of cows that were pregnant after Al during the subsequent oestrus were $0.40,0.50$ and 0.50 for the control, HSLF and HSLFLSHF, respectively (Table 1). Although they were not compared statistically in the current study, several physiological events influence the expression of oestrus and pregnancy rates in dairy cows. The root cause of poor oestrous expression (poor intensity and duration) is related to low circulating oestradiol levels, owing to its high metabolic clearance rate (Sangsritavong et al., 2002) and low plasma LH, insulin, and IGF-I levels induced by the NEB (Diskin et al., 2007; Garnsworthy et al., 2008a) and stress (Dobson et al., 2008). Coupled with poor oestrous expression, an inability to detect oestrus easily could impede Al from being performed at the correct time (Walsh et al., 2011; Thatcher, 2017). Whether the energy sources and intake levels affected fertility outcomes (Butler, 2000; 2003; Gong et al., 2002a; 2002b; Garnsworthy et al., 2008b; 2008c; Santos et al., 2008) remains to be investigated under field conditions and a longer postpartum period (i.e. 305 DIM).

\section{Conclusion}

In this study, no differences were observed between nutritional treatments in the dimensions of the ovaries and the preovulatory follicles and numbers of follicles in various classes in dairy cows. However, grazing cows that received high $(12.6 \mathrm{~kg} /$ day) levels of concentrates in the HSLF and HSLF-LSHF treatments recorded a higher number of total follicles, compared with those on the low $(7 \mathrm{~kg} / \mathrm{day})$ level of concentrate in the control group. This response was related to the increase in total nutrient intake and ME, which supported an improvement of ovarian follicular growth in the HSLF and HSLF-LSHF treatments in comparison with the control. Future research needs to investigate the influence of various inclusion levels and sources of energy nutrients that enhance the viability and the quality of the oocyte ovulating from the dominant follicle and improve the intensity and length of the oestrous expression in dairy cows. Also, effects of types and levels of dietary energy nutrients on pregnancy rates with a large number of cows under field conditions and a longer postpartum period (i.e. 305 DIM) require further investigation.

\section{Acknowledgements}

The authors express gratitude to Western Cape Department of Agriculture (WCDA) for permission to use the facilities and data towards a PhD study for Mr Useni at the University of Stellenbosch. The support of the workers and management at the dairy section of Elsenburg Research Farm is greatly appreciated. The authors also thank Dr. A. Kidd of Stellenbosch Veterinary Hospital for all veterinary assistance and ultrasound procedures. This study was funded by Western Cape Agricultural Research Trust (WCART) with technical support by the WCDA. Mr Useni acknowledges the financial support from the WCART towards his PhD studies.

\section{Authors' Contributions}

Conception and design of the trial: BAU and CJCM; data collection and analysis: BAU; drafting of paper: BAU; critical revision: CJCM; final approval of version to be published: CWC.

\section{Conflict of Interest Declaration}

The authors certify that they have no affiliations with any organization or entity with any financial or non-financial interest in the subject matter or materials discussed in this manuscript. 


\section{References}

Adamiak, S.J., Mackie, K., Watt, R.G., Webb, R. \& Sinclair, K.D., 2005. Impact of nutrition on oocyte quality: Cumulative effects of body composition and diet leading to hyperinsulinemia in cattle. Biol. Reprod. 73, 918-926.

Armstrong, D.G., McEvoy, T.G., Baxter, G., Robinson, J.J., Hogg, C.O., Woad, K.J., Webb, R. \& Sinclair, K.D., 2001. Effect of dietary energy and protein on bovine follicular dynamics and embryo production in vitro: Associations with the ovarian insulin-like growth factor system. Biol. Reprod. 64, 1624-1632.

AOAC, 1990. Official methods of analysis, 14th edition. Association of official analytical chemists, Washington, DC, USA.

Barnes, F., Endebrock, M., Looney, C., Powell, R., Westhusin, M. \& Bondioli, K., 1993. Embryo cloning in cattle: The use of in vitro matured oocytes. J. Reprod. Fertil. 97, 317-320.

Beam, S.W. \& Butler, W.R., 1997. Energy balance and ovarian follicle development prior to first ovulation postpartum in dairy cows receiving three levels of dietary fat. Biol. Reprod. 56, 133-142.

Beam, S.W. \& Butler, W.R., 1999. Effects of energy balance on follicular development and first ovulation in postpartum dairy cows. J. Reprod. Fertil. 54, 411-424.

Blondin, P. \& Sirard, M.A., 1995. Oocyte and follicular morphology as determining characteristics for developmental competence in bovine oocytes. Mol. Reprod. Dev. 41, 54-62.

Blondin, P., Vigneault, C., Nivet, A.L. \& Sirard, M.A., 2012. Improving oocyte quality in cows and heifers: What have we learned so far? Anim. Reprod. 9, 281-289.

Britt, J.H., 1994. Follicular development and fertility: Potential impacts of the negative energy balance. In: Proc. Nat. Reprod. Symp. Pittsburgh. pp. 103-112.

Butler, W.R., 2000. Nutritional interactions with reproductive performance in dairy cattle. Anim. Reprod. Sci. 60-61, 449457.

Butler, W.R., 2003. Energy balance relationships with follicular development, ovulation and fertility in postpartum dairy cows. Livest. Prod. Sci. 83, 211-218. CPM-Dairy, 2006. Cornell Penn Miner Dairy Cattle Ration Analyser, Version 3.0.8, USA.

Diskin, M.G., Smith, R., Royal, M., Knight, C. \& Sheldon, I., 2007. The high producing dairy cow and its reproduction performance. Reprod. Domest. Anim. 42, 17-23.

Dobson, H., Walker, S.L., Morris, M.J., Routly, J.E. \& Smith, R.F., 2008. Why is it getting more difficult to successfully artificially inseminate dairy cows? Animal 2, 1104-1111.

Fricke, P.M., 2002. Scanning the future: Ultrasonography as a reproductive management tool for dairy cattle. J. Dairy Sci. 85, 1918-1926.

Garnsworthy, P.C., Sinclair, K.D. \& Webb, R., 2008a. Integration of physiological mechanisms that influence fertility in dairy cows. Animal 2, 1144-1152.

Garnsworthy, P.C., Lock, A., Mann, G.E., Sinclair, K.D. \& Webb, R., 2008b. Nutrition, metabolism and fertility in dairy cows: 1. Dietary energy source and ovarian function. J. Dairy Sci. 91, 3814-3823.

Garnsworthy, P.C., Lock, A., Mann, G.E., Sinclair, K.D. \& Webb, R., 2008c. Nutrition, metabolism and fertility in dairy cows: 2. Dietary fat content and ovarian function. J. Dairy Sci. 91, 3824-3833.

Gong, J.G., Armstrong, D.G., Baxter, G., Hogg, C.O., Garnsworthy, P.C. \& Webb, R., 2002a. The effect of increased dietary intake on superovulatory response to $\mathrm{FSH}$ in heifers. Theriogenology 57, 1591-1602.

Gong, J.G., Lee, W.J., Garnsworthy, P.C. \& Webb, R., 2002b. Effect of dietary-induced increases in circulating insulin concentrations during the early postpartum period on reproductive function in dairy cows. Reprod. 123, 419-427.

Ireland, J.L.H., Scheetz, D., Jimenez-Krassel, F., Themen, A.P.N., Ward, F., Lonergan, P., Smith, G.W., Perez, G.I., Evans, A.C.O. \& Ireland, J.J., 2008. Antral follicle count reliably predicts number of morphologically healthy oocytes and follicles in ovaries of young adult cattle. Biol. Reprod. 79, 1219-1225.

Jimenez-Krassel, F., Folger, J., Ireland, J.L.H., Smith, G.W., Hou, X., Davis, J.S., Lonergan, P., Evans, A.C.O. \& Ireland, J.J., 2009. Evidence that high variation in ovarian reserves of healthy young adults has negative impact on the corpus luteum and endometrium during reproductive cycles of single-ovulating species. Biol. Reprod. 80, 12721281.

Jolly, P.D., McDougall, S., Fitzpatrick, L.A., Macmillan, K.L. \& Entwistle, K.W., 1995. Physiological effects of undernutrition on postpartum anoestrus in cows. J. Reprod. Fertil. Suppl. 49, 477-492.

Laskowski, D., Sjunnesson, Y., Humblot, P., Andersson, G., Gustafsson, H. \& Båge, R., 2016. The functional role of insulin in fertility and embryonic development: What can we learn from the bovine model? Theriogenology 86 , 457-464.

Leroy, J.L.M.R., Opsomer, G., Van Soom, A., Goovaerts, I.G.F. \& Bols, P.E.J., 2008a. Reduced fertility in high-yielding dairy cows: Are the oocyte and embryo in danger? Part I. The importance of negative energy balance and altered corpus luteum function to the reduction of oocyte and embryo quality in high-yielding dairy cows. Reprod. Domest. Anim. 43, 612-622.

Leroy, J.L.M.R., Van Soom, A., Opsomer, G., Goovaerts, I.G.F \& Bols, P.E.J., 2008b. Reduced fertility in high-yielding dairy cows: Are the oocyte and embryo in danger? Part II. Mechanisms linking nutrition and reduced oocyte and embryo quality in high-yielding dairy cows. Reprod. Dom. Anim. 43, 623-632.

Letelier, C., Mallo, F., Encinas, T., Ros, J.M. \& Gonzalez-Bulnes, A., 2008. Glucogenic supply increases ovulation rate by modifying follicle recruitment and subsequent development of preovulatory without effects on ghrelin secretion. Reprod. 136, 65-72.

Lonergan, P., Monaghan, P., Rizos, D., Boland, M.P. \& Gordon, I., 1994. Effect of follicle size on bovine oocyte quality and developmental competence following maturation, fertilization and culture in vitro. Mol. Reprod. Dev. 37, 48-53.

Lucy, M.C., 2003. Mechanisms linking nutrition and reproduction in postpartum cows. Reprod. Suppl. 61, 415-427. 
Lucy, M.C., 2007. Fertility in high-producing dairy cows: Reasons for decline and corrective strategies for sustainable improvement. Soc. Reprod. Fertil. Suppl. 64, 237-254.

Lucy, M.C., Staples, C.R., Michel, F.M. \& Thatcher, W.W., 1991a. Energy balance and size and number of ovarian follicles detected by ultrasonography in early postpartum dairy cows. J. Dairy Sci. 74, 473-482.

Lucy, M.C., Staples, C.R., Michel, F.M., Thatcher, W.W. \& Bolt, D.J., 1991b. Effect of feeding calcium soaps to early postpartum dairy cows on plasma prostaglandin- $F_{2 \alpha}$, luteinizing hormone and follicular growth. J. Dairy Sci. 74 , 483-489.

Mellouk, N., Rame, C., Touzé, J.L., Briant, E., Ma, L., Guillaume, D., Lomet, D., Caraty, A., Ntallaris, T., Humblot, P. \& Dupont, J., 2017. Involvement of plasma adipokines in metabolic and reproductive parameters in Holstein dairy cows fed with diets with differing energy levels. J. Dairy Sci. 100, 8518-8533

Moallem, U., Katz, M., Arieli, A. \& Lehrer, H., 2007. Effects of peripartum propylene glycol or fats differing in fatty acid profiles on feed intake, production and plasma metabolites in dairy cows. J. Dairy Sci. 90, 3846-3856.

Mossa, F., Walsh, S.W., Butler, S.T., Berry, D.P., Carter, F., Lonergan, P., Smith, G.W., Ireland, J.J. \& Evans, A.C.O., 2012. Low numbers of ovarian follicles $\geq 3 \mathrm{~mm}$ in diameter are associated with low fertility in dairy cows. J. Dairy Sci. 95, 2355-2361.

Roche, J.F., Mackey, D. \& Diskin, M.D., 2000. Reproductive management of postpartum cows. Anim. Reprod. Sci. 6061, 703-712.

Roche, J.R., Burke, C.R., Meier, S. \& Walker, C.G., 2011. Nutrition x reproduction interaction in pasture-based systems: Is nutrition a factor in reproductive failure? Anim. Prod. Sci. 51, 1045-1066.

Sakaguchi, M., Sasamoto, Y., Suzuki, T., Takahashi, Y. \& Yamada., Y., 2004. Postpartum ovarian follicular dynamics and oestrous activity in lactating dairy cows. J. Dairy Sci. 87, 2114-2121.

Sangsritavong, S., Combs, D.K., Sartory, R., Armentano, L.E. \& Wiltbank, M.C., 2002. High feed intake increases liver blood flow and metabolism of progesterone and oestradiol-17ß in dairy cattle. J. Dairy Sci. 85, 2831-2842.

Santos, J.E.P., Bilby, T.R., Thatcher, W.W., Staples, C.R. \& Silvestre, F.T., 2008. Long chain fatty acids of diet as factors influencing reproduction in cattle. Reprod. Dom. Anim. 43, 23-30.

SAS, 2012. Statistical Analysis Systems. SAS Enterprise Guide Software, Version 5.1. SAS ${ }^{\circledR}$ Institute Inc., Cary, North Carolina, USA.

Scaramuzzi, R.J., Baird, D.T., Campbell, B.K., Driancourt, M.A., Dupont, J., Fortune, J.E., Gilchrist, R.B., Martin, G.B., McNatty, K.P., McNeilly, A.S., Monget, P., Monniaux, D., Viñoles, C. \& Webb, R., 2011. Regulation of folliculogenesis and determination of ovulation rate in ruminants. Reprod. Fertil. Dev. 23, 444-467.

Schillo, K.K., 1992. Effects of dietary energy on control of luteinizing hormone secretion in cattle and sheep. J. Anim. Sci. $70,1271-1282$.

Staples, C.R., Burke, J.M. \& Thatcher, W.W., 1998. Influence of supplemental fats on reproductive tissues and performance of lactating cows. J. Dairy Sci. 81, 856-871.

Taylor, V.J., Beever, D.E. \& Wathes, D.C., 2003. Physiological adaptations to milk production that affect fertility in high yielding dairy cows. In: Dairying, using science to meet consumer needs. Ed. Kerbreab, E., Mills, J. \& Beever, D. Br. Soc. Anim. Sci. Occasional Publicat., Nottingham University 29, pp. 37-71.

Thatcher, W.W., 2017. A 100-year review: Historical development of female reproductive physiology in dairy cattle. J. Dairy Sci. 100, 10272-10291.

Van Knegsel, A.T.M., Van den Brand, H., Dijkstra, J., Van Straalen, W.M., Heetkamp, M.J.W., Tamminga, S. \& Kemp, B., 2007. Dietary energy source in dairy cows in early lactation: Energy partitioning and milk composition. J. Dairy Sci. 90, 1467-1476.

Van Soest, P.J., Robertson, J.B. \& Lewis, B.A., 1991. Methods for dietary fibre, neutral detergent fibre and non-starch polysaccharides in relation to animal nutrition. J. Dairy Sci. 74, 3583-3597.

Vasconcelos, J.L.M., Sartori, R., Oliveira, H.N., Guenther, J.G. \& Wiltbank, M.C., 2001. Reduction in size of the ovulatory follicle reduces subsequent luteal size and pregnancy rate. Theriogenology 56, 307-314.

Walsh, S.W., Williams, E.J. \& Evans, A.C.O., 2011. A review of the causes of poor fertility in high milk producing dairy cows. Anim. Reprod. Sci. 123, 127-138.

Wathes, D.C., Taylor, V.J., Chenz, Z. \& Mann, G.E., 2003. Follicle growth, corpus luteum function and their effects on embryo development in the postpartum cow. Reprod. Suppl. 61, 219-237.

Wathes, D.C, Abayasekara, D.R.E. \& Aitken, R.J., 2007. Polyunsaturated fatty acids in male and female reproduction. Biol. Reprod. 77, 190-201.

Watson, A.J., 2007. Oocyte cytoplasmic maturation: A key mediator of oocyte and embryo developmental competence. J. Anim. Sci. 85 (Suppl E), E1-E3.

Webb, R., Garnsworthy, P.C., Gong, J.G. \& Armstrong, D.G., 2004. Control of follicular growth: Local interactions and nutritional influences. J. Anim. Sci. 82, E63-E74. 